\title{
ISOLATED VELOPALATINE PARALYSIS ASSOCIATED WITH PARVOVIRUS B19 INFECTION
}

\author{
João P. Soares-Fernandes', Ricardo Maré2
}

ABSTRACT - A case of isolated velopalatine paralysis in an 8-year-old boy is presented. The symptoms were sudden-onset of nasal speech, regurgitation of liquids into the nose and dysphagia. Brain MRI and cereb rospinal fluid examination were normal. Infectious serologies disclosed an antibody arrangement towards panovirus B19 that was typical of recent infection. In the absence of other positive data, the possibility of a correlation between the tenth nerve palsy and parvovirus infection is discussed.

KEY WORDS: paralysis, vagus nerve, palate, parvovirus B19, infection, childhood.

\begin{abstract}
Paralisia velopalatina isolada associada a infecção por parvovírus B 19
RESUMO - Apresentamos um caso de paralisia velopalatina isolada, num menino de 8 anos, que se manifestou por voz nasalada, regurgitação de líquidos pelo nariz e disfagia, de início súbito. A ressonância magnética encefálica e o estudo do líquido cefalo-raquidiano foram normais. O perfil serológico dos anticorpos anti-parvovírus B19 era típico de infecção recente. Na ausência de outros dados positivos, discute-se a possibilidade de uma correlação entre a parésia do X nervo e a infecção por parvovírus.
\end{abstract}

PALAVRAS-CHAVE: paralisia, nervo vago, palato, parvovirus B19, infecção, criança.

Unilateral isolated paralysis of the soft palate is uncommon. Since the first description, by Edin et al in 19761, 30 cases have been re ported, all of them in childhood or adolescence ${ }^{2}$. Patients typically present sudden onset of nasal speech and dysfagia with complete recoveryin weeks or months. In four of the rep o rted cases, a concomitant viral infection was diagnosed. Implicated viruses include varicella-zoster virus $(\mathrm{VZV})^{3}$, herpes simplex virus (HSV) ${ }^{4}$, measles virus ${ }^{5}$ and Coxsackie $A 9$ virus ${ }^{6}$. Despite the increased availability of diagnostic tests, the aetiology of acquired velopalatine palsy remains largely unknown.

We present a case of unilateral velopalatine palsy associated with parvovirus infection in an 8-yearold male patient.

\section{CASE}

A previously healthy 8-year-old boy was brought to our e m e rgency department for sudden ons et, 3 days before, of nasal speech, regurgitation of liquids into the nose and difficulty in swallowing. One week before, he referred diarrhoea, which resolved spontaneously in two days. He denied headaches, vomits, cervical pain or visual disturbance. There was, also, no traumatic or toxic ingestion history.

On examination, he had a fine general appearance. In phonation, uvula deviated to the right due to left soft hemipalate palsy (Figure). The pharyngeal reflex and the vocal cords were intact. The exploration of the remaining cranial nerves was normal.

Laboratoryanalysis, including blood cell count, erythrocyte sedimentation rate, C-reactive protein, thyroid function, vitamin B12, folic acid, antinuclear, anti-double-stranded DNA, antineutrophil cytoplasmic and antihistone antibodies were normal or unremarkable. Results of laboratory tests for viruses known to be associated with isolated velopalatine paralysis in childre $n^{3-6}$ we re negative. Instead, the search disclosed an antibody arrangement towards parvo virus B19 that was typical of recent infection (IgM titer 2.1 and IgG titer 1.73). CSF cytochemical examination was normal. CSF PCR testing for HSV 1 and 2, HHV6, CMV, EBV and entero $v$ i rus $w$ as negative. No bacteria or fungi were cult u redfrom the CSF. Cerebral MRI (including diffusion-

Departments of Neuroradiology and Neurology, Hospital de S. Marcos, Braga, Portugal and School of Health Sciences, University of Minho, Braga, Portugal: 'Resident in Neuroradiology - Department of Neuroradiology, Hospital de S. Marcos, Braga, Portugal; and Assistant Professor of Physiology - School of Health Sciences, University of Minho, Braga, Portugal; ${ }^{2}$ Consultant Neurologist Department of Neurology, Hospital de S. Marcos, Braga, Portugal.

Received 19 January 2006. Accepted 29 April 2006.

Dr. João Paulo Soares-Fernandes - Serviço de Neurorradiologia - Hospital de S. Marcos - Largo Engenheiro Carlos Amarante - Apartado 2242 - 4701-965 Braga - Portugal. E-mail: jsfernandes@ecsaude.uminho.pt 


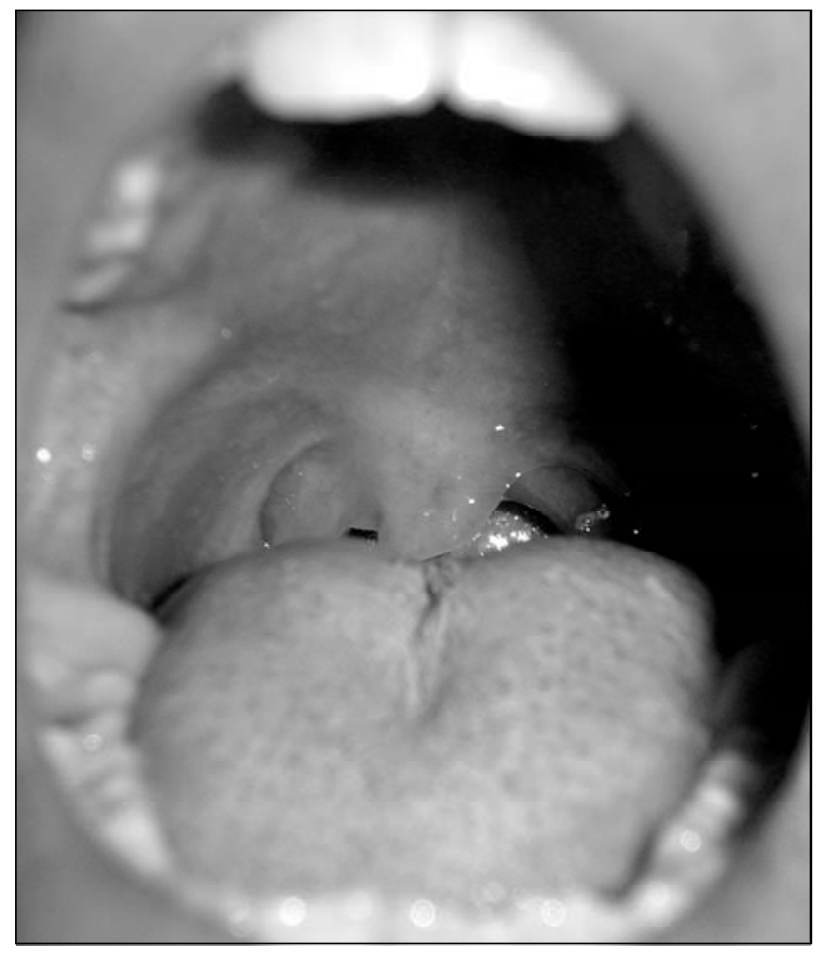

Figure. Patient's palate photograph, obtained in phonation, shows uvula's deviation to the right, due to left hemipalate palsy.

weighted imaging and magnetic resonance angiography), obtained 72 hours after the beginning of the symptoms, was normal.

No treatment was instituted. In 10 weeks, the symptoms resolved and the anti-Parvovirus IgM titer lowered to 0.9 , while the $\lg G$ titer rose to 2.3 .

\section{DISCUSSION}

Isolated acquired velopalatine hemiparalysis is rare, afflicting patients in their first or second decades of life. Eighty percent of the re p o rted cases occurre d in male patients ${ }^{7}$. Establishing idiopathic aetiology requires exclusion of other conditions, mainly traumatic (including recent adenoidectomy) and toxic or pha rmacological. Besides laboratory investigation, ce rebral MRI must be perf o rmed, as it allows excluding pontocerebellar or brainstem expansive lesions, ischemia and demyelination.

As in Bell's palsy, postulated physiopathology bases on neuritis, causing sudden palsy of the tenth cranial nerve. Neuritis may be the result of viral infection or immunological/inflammatory lesion. In previous re ports, 10 patients presented symptoms of infectious disease (gastroenteritis and high respiratory pathways infection) but only 4 of them had specific serologic evidence of viral aetiology ${ }^{7}$. In Sullivan and Carlson's patient, an elevated herpes simplex immunoglobulin titer was demonstrated ${ }^{4}$. Auberg e reported elevated measles immunoglobulin titer in one of his five patients 5 . Viral cultures yielded Coxsackie B9 in Nussey's patient ${ }^{6}$.

Human parvovirus B19 is the smallest DNA virus (18 to $24 \mathrm{~nm}$ ) known to infect humans. It causes a common childhood disease, re $f$ e rred to as ery the ma infectiosum, or fifth disease. Human parvovirus B19 horizontal transmission is common, mainly through the respiratoryroute. Frequencies of parv o $v$ i rus B19 seropositivity reaching $50 \%$ in young people and $90 \%$ in the elderly have been reported ${ }^{8}$.

Infection with parvovirus B19 is usually a mild selflimiting disease: $25 \%$ of all infected individuals are asymptomatic, $50 \%$ have only mild non-specific symptoms, like low-grade fever, coryza, headache, and/or mild gastrointestinal symptoms ${ }^{9}$. Only $25 \%$ of all infected individuals present with the typical "slapped cheek" rash or arthralgia 8 .

In immunocompetent individuals, serological testing should be perf o rmed, when attempting to diagnose acute parvovirusB19 infection, since PCR analysis to detect viral DNA may be negative in up to $55 \%$ of cases $^{10}$.

Parvovirus B19-specific IgM remains measurable for 2 to 3 months after the initial infection, before decreasing to undetectable levels. Parvovirus B19-specific IgG antibody production occurs as soon as 10 days after infection, almost as quickly as parvovirus B19-specific IgM is detectable ${ }^{10}$.

A MEDLINE search failed to yield bibliographic references on a possible correlation between velopalatine paralysis and parvo vi rus B19 infection. Neurologic complications of parvovirus B19 infections were firstly suggested by reports of encephalopathy in patients with erythema infectiosum ${ }^{11}$. Subsequently, neuropathies (including optic neuropathy and brachial plexitis), meningitis, meningoencephalitis, transverse myelitis, Guillain-Barré syndrome and stroke have been reported ${ }^{12,13}$. In peripheral neuropathy, meningoencephalitis and transverse myelitis, proposed pathophysiology bases on formation of antibody-antigen complexes. Immune complexes can accumulate between the endothelial cells in the vessels feeding the nervous tissues, resulting in pro d u ction of lysoenzimes, causing restricted blood flow and various symptoms ${ }^{12}$. In this child, this mechanism was likely involved, since the IgG titer was already elevated on presentation, allowing the formation of immune complexes. 
The favourable outcome is in agreement with the usually benign course of B19-associated neurological manifestations. In most of the cases, only supplementary treatment is needed until the virus is cleared by the immune system. If persistent symptoms occur, treatment with intravenous immunoglobulin may be useful ${ }^{12}$.

In conclusion, our findings strongly suggest that parvovins B19, in addition to known viruses, may be responsible for velopalatine paralysis in children and, even when medical evaluation fails to disclose specific clinical signs of recent or ongoing viral infection, a viral aetiology should not be excluded.

\section{REFERENCES}

1. Edin $\mathrm{M}$, Sveger $\mathrm{T}$, Tegner $\mathrm{H}$, Tjernström O. Isolated temporary pharyngeal paralysis in childhood. Lancet 1976;1:1047-1049.

2. Jary A, Maillard L, Raffo E, Ducrocq X, Braun M, Vespignani H. Acute, isolated and reversible paralysis of the soft palate in childhood. Rev Neurol (Paris) 2004;160:836-838.

3. Izzat M, Sharma PD. Isolated bilateral paralysis of the soft palate in an adult. J Laryngol Otol 1992;106:839-840.

4. Sullivan JL, Carlson CB. Isolated temporary pharyngeal paralysis in childhood. Lancet 1976;2:863.

5. Auberge C, Ponsot G, Gayraud P, Bouygues D, Arthuis M. Les hemiparalysis velopalatines isolées et acquises chez l'enfant. Arch Franç Pédiatrie 1979;36:283-286.

6. Nussey AM. Paralysis of palate in a child. Br Med J 1977;2:165-166.

7. Villarejo-Galende A, Camacho-Salas A, Penas-Prado M, et al. Unilateral isolated paralysis of the soft palate: a case report and a review of the literature. Rev Neurol 2003;36:337-339.

8. Anderson LJ, Tork JJ. The clinical spectrum of human Parvovirus B19 infections. Curr Clin Top Infect Dis 1991;11:267-280.

9. Woolf AD, Capion GV, Chishick A, et al. Clinical manifestations of human parvovirus B19 in adults. Arch Intern Med 1989;149:1153-1156.

10. Jordan JA. Diagnosing human parvovirus B19 infection: guidelines for test selection. Mol Diagn 2001;6:307-312.

11. Balfour HH Jr, Schiff GM, Bloom JE. Encephalitis associated with erythema infectiosum. J Pediatr 1970;77:133.

12. Barah F, Vallely PJ, Cleator GM, Kerr JR. Neurological manifestations of human parvovirus B19 infection. Rev Med Virol 2003;13:185-199.

13. Guidi B, Bergonzini P, Crisi G, Frigieri G, Portolani M. Case of stroke in a 7-year-old male after parvovirus B19 infection. Pediatr Neurol 2003;28:69-71. 